\title{
Studi Komparatif Pola Pengelolaan Sekolah Islam Berasrama Antara SMAIT Ihsanul Fikri dan SMAI Al Azhar
}

\section{A comparative study of boarding school management system between SMAIT Ihsanul Fikri and SMAI Al Azhar}

Received: 01-09-2020; Revised: 29-11-2020; Accepted: 14-12-2020; Published: 29-12-2020

\section{Amin Maghfuri *)}

Universitas Islam Negeri Sunan

Kalijaga Yogyakarta, Indonesia.

E-mail:aminmaghfuri@yahoo.com

\section{Suwadi}

Universitas Islam Negeri Sunan Kalijaga Yogyakarta, Indonesia. E-mail: suwadi@uin-suka.ac.id

*) Corresponding Author

\begin{abstract}
In recent years, many Islamic schools have started to innovate by offering a boarding component in their education system. This research intends to examine how the combination of schools and pesantren which is manifested in the form of an Islamic school with boarding system is managed and how the curriculum is implemented in this combination system. This research is a qualitative research that focuses on a comparative study between SMAIT Ihsanul Fikri Boarding School and SMAI Al Azhar Boarding School. The research data were collected using interview, observation and documentation techniques. By using descriptive analysis, the results of this study indicate that 1) The management pattern of islamic school with boarding systems in the two educational institutions shows differences, especially in the structural position of the person in charge of boarding schools as an element of boarding school institutions; 2) Curriculum implementation as a consequence of a combination of two systems in islamic school with boarding system is also different, one of which is more on systemic integration while the other is more on organic integration.
\end{abstract}

\begin{abstract}
Abstrak: Dalam beberapa tahun terakhir, banyak sekolah-sekolah Islam yang mulai berinovasi dengan menawarkan komponen asrama dalam sistem pendidikannya. Penelitian ini hendak mengkaji bagaimana kombinasi sekolah dan pesantren yang termanifestasikan dalam bentuk sekolah berasrasma dikelola serta bagaimana penyelenggaraan kurikulum di dalam sistem kombinasi tersebut. Penelitian ini adalah penelitian kualitatif yang berfokus pada studi komparasi antara SMAIT Ihsanul Fikri Boarding School dan SMAI Al Azhar Boarding School. Data penelitian dikumpulkan dengan teknik wawancara, observasi dan dokumentasi. Dianalisis dengan pendektan analisi deskriptif, hasil penelitian ini menunjukkan bahwa 1) pola pengelolaan kelembagaan sekolah berasrama pada dua lembaga pendidikan tersebut menunjukkan perbedaan, terutama pada posisi struktural penanggung jawab asrama sebagai unsur kelembagaan sekolah berasrama; 2) implementasi kurikulum sebagai konsekuensi kombinasi dua sistem dalam kelembagaan sekolah berasrama juga berbeda, satu diantaranya lebih pada integrasi sistemik sedangkan yang lain lebih pada integrasi organik.
\end{abstract}

Keywords: Islamic School, Boarding, Integration, Institutional Management 


\section{PENDAHULUAN}

$\mathrm{B}$ eberapa tahun terakhir, popularitas sekolah berasrama mengalami peningkatan yang cukup pesat. Hal ini misalnya dapat dilihat dari semakin menjamurnya sekolah dengan sistem asrama yang menawarkan berbagai keunggulan. Keberadaannya dapat menjadi pilihan alternatif bagi orang tua sebagai tempat belajar yang tepat bagi anakanaknya. Dengan menerapkan sistem asrama, sekolah dengan model ini dianggap sebagai perpaduan antara sistem sekolah dan sistem pesantren dalam bentuk yang lebih modern. Maka tidak mengherankan jika sekolah dengan sistem asrama ini memiliki daya tawar yang tinggi, terutama bagi kalangan menengah-urban.

Bermunculannya sekolah Islam berasrama patut diduga merupakan respon terhadap kondisi pendidikan di Indonesia serta kelanjutan dari penerapan sekolah Islam terpadu, khususnya penerapan sistem full day school. Sekolah Islam terpadu sendiri secara garis besar memiliki tujuan memberikan pembelajaran sains yang unggul serta menanamkan nilai-nilai keislaman yang cukup (Hefner, 2009; Suyatno, 2013). Penekanan pada nilai-nilai keislaman umumnya menjadi karakter khusus dengan tetap mempertahankan keunggulan di bidang sains sebagaimana sekolah pada umumnya. Waktu pembelajaran yang lebih panjang melalui penerapan full day school memungkinkan Sekolah Islam Terpadu untuk mengajarkan semua materi yang diharuskan dalam kurikulumnya, termasuk tambahan kurikulum agama, Bahasa Arab dan Alqur'an yang dipercaya menjadi kekhasannya (Hasan, 2009). Penerapan sistem pembelajaran yang demikian tersebut sekaligus memberikan keuntungan bagi orang tua yang memiliki kesibukan bekerja dari pagi sampai sore. Dengan sistem tersebut, mereka tidak perlu khawatir dengan aktifitas anaknya karena tetap berada dalam pengawasan guru atau sekolah.
Melalui penerapan sistem asrama, penanaman dan penguatan nilai-nilai keislaman pada diri peserta didik diproyeksikan menjadi semakin efektif serta lebih komprehensif. Tanggung jawab memberikan pengetahuan keagamaan, menanamkan serta mendidik kesalehan dan moralitas dapat dilakukan dengan lebih sistematis dan intensif pada sekolah yang menerapkan sistem asrama (boarding school) tersebut. Mengingat siswa tinggal di asrama yang terletak di lingkungan sekolah, mereka memiliki waktu yang lebih panjang untuk berinteraksi dengan guru atau pembimbing dan belajar untuk mengaplikasikan apa yang telah dipelajari di ruang kelas (Hasan, 2009).

Kemunculan sekolah Islam dengan sistem asrama merupakan hasil dari proses transformasi pendidikan Islam, yang lahir sebagai model baru sistem pendidikan dengan tujuan memperbaiki sistem pendidikan Islam yang dirasa cenderung sekuler (Maksudin, 2012). Sepanjang sejarah pendidikan Indonesia sendiri, setidaknya dapat dicatat beberapa upaya yang dilakukan dalam rangka memformulasikan format pendidikan yang ideal yang sesuai dan compatible dengan kondisi Indonesia untuk mengejar kemajuan tanpa kehilangan identitas religiusnya. Upaya-upaya tersebut di antaranya tampak dalam proses modernisasi pesantren (Lukens-Bull, 2005; Yasmadi, 2002), peningkatan mutu pendidikan madrasah (Maghfuri \& Rasmuin, 2019; Maksum, 1999), internalisasi pendidikan agama di sekolah umum (Kosim, 2006; Magdalena, 2013), serta berbagai upaya lainnya.

Meski bukan satu-satunya tren yang sedang berkembang saat ini, pertumbuhan dan persebaran sekolah Islam berasrama patut dipertimbangkan sebagai gelombang baru inovasi pendidikan, khusunya dalam konteks pendidikan Islam. Ekspektasi yang tinggi diemban oleh lembaga pendidikan dengan sistem asrama ini, mengingat salah satu diantara alasan kemunculannya adalah 
untuk menjembatani dikotomi keilmuan yang tidak kunjung selesai. Umumnya, sekolah berasrama dianggap sebagai manifestasi perpaduan antara pesantren dan sekolah. Dengan keunggulan yang dimiliki masing-masing, perpaduan ini dipercaya akan menghasilkan sistem yang lebih kuat dan lengkap (Saepudin, 2019). Melalui sistem asrama ini, jurang-jurang pemisah antara pendidikan umum dan pendidikan agama dapat disatukan dalam kerangka integratif yang tentunya dapat menghasilkan lulusan yang utuh (insan kamil). Dengan sistem pendidikan yang diterapkan, pendidikan di boarding school digadang-gadang dapat melahirkan lulusanlulusan yang kompeten dalam bidang science dan teknologi serta memiliki jiwa dan karakter yang islami. Dua kriteria inilah yang belum mampu dihasilkan sekaligus oleh sistem pendidikan sebelumnya, baik sistem pesantren maupun sistem persekolahan (Arifin, 2012).

Berdasarkan penelitian Thohir (2017), ciri khas dan keunggulan sistem pendidikan pesantren berupa penerapan pendidikan selama 24 jam, dimana para santri diwajibkan tinggal menetap di dalamnya, menjadi bagian yang menarik dan pada akhirnya diadopsi oleh lembaga pendidikan lain. Atas dasar itu pula, banyak sekolah Islam yang berinovasi dengan menambahkan komponen asrama dalam sistem pendidikannya sebagai representasi pesantren. Langkah ini dianggap sebagai metode yang tepat untuk menyatukan keunggulan yang ada dalam sistem pendidikan sekolah dan sistem pesantren. Menurut Amrizal (2011), perpaduan sistem sekolah dan sistem pesantren dalam satu lembaga pendidikan merupakan salah satu solusi permasalah pendidikan yang ada.

Fenomena sekolah berasrama memiliki kesamaan dengan gelombang pembukaan madrasah atau sekolah di lingkungan pesantren pada periode sebelumnya, meski memiliki pola yang berbeda. Sebagaimana dipaparkan dalam penelitian Fauzan (2017), dibukanya lembaga pendidikan formal di lingkungan pesantren dari tingkat dasar sampai perguruan tinggi merupakan contoh terlaksananya integrasi kurikulum di pesantren. Keberadaan madrasah atau sekolah dalam lingkungan pesantren ini dianggap sebagai langkah strategis pihak pesantren dalam memperbaiki sistem pendidikannya. Semangat untuk memperbaiki sistem pendidikan serta agar dapat menghasilkan lulusan yang kompetitif ini pula yang mendasari kelahiran sekolah dengan sistem asrama.

Meski demikian, sebagai sistem perpaduan antara pesantren dan sekolah, pengelolaan sekolah Islam berasrama belum memiliki pola yang baku, baik dari sisi kelembagaan maupun dari sisi kurikulum. Sebagaimana diungkapkan oleh Muhdi (2018), idealnya kombinasi antara sistem pesantren dan sistem persekolahan harus meliputi aspek keilmuan dan aspek menajemen yang dilakukan secara komprehensif. Penggabungan dua sistem yang memiliki ciri dan karakter masingmasing ke dalam satu sistem yang terpadu menuntut usaha yang serius sehingga perpaduan yang berlangsung dapat mengakomodasi keunggulan-keunggulan yang ada secara seimbang tanpa mereduksi salah satunya. Hal ini berlaku pula pada aspek kurikulum, dimana perpaduan antara kurikulum pesantren dan kurikulum persekolahan merupakan aspek yang diunggulkan. Akomodasi yang tidak seimbang terhadap karakter, fungsi serta kaunggulan dari keduanya berpotensi menjadi celah kelemahan dalam upaya mewujudkan cita-cita pendidikan yang integral, dan menempatkan salah satunya hanya sebagai pelengkap terhadap yang lain.

Dengan mempertimbangkan alasan tersebut, penelitian ini dimaksudkan untuk menggali, menganalisis dan mendeskripsikan pola pengelolaan sekolah Islam dengan sistem asrama yang merepresentasikan perpaduan sistem pesantren dan sistem persekolahan. Dengan sistem yang diterapkan tersebut, apakah 
komponen dan karakteristik sekolah maupun pesantren dapat diakomodasi secara proporsional dalam sistem perpaduan tersebut. Secara lebih spesifik, penelitian ini akan mengkaji bagaimana pengelolaan kelembagaan antara unsur pesantren dan unsur sekolah dalam sistem sekolah Islam berasrama. Selain itu, penelitian ini juga akan mengkaji seperti apa konsekuensi perpaduan dua sistem tersebut terhadap pengelolaan kurikulum. Pada aspek kurikulum inilah akan tercermin seperti apa lulusan yang diharapkan dapat dihasilkan dari sistem perpaduan tersebut. Dengan menggunakan pendekatan komparatif, penelitian ini berusaha mengkaji pola pengelolaan yang berlangsung di SMAIT Ihsanul Fikri Boarding School dan SMAI Al Azhar Boarding School. Selain karena kedua lembaga ini menerapkan sekolah dengan sistem asrama serta mengakui asrama sebagai representasi perwujudan sistem pesantren, pada studi pendahuluan keduanya menunjukkan pola pengelolaan yang relatif berbeda. Hal tersebut mengindikasikan peluang adanya variasi pola pengelolaan dalam sistem sekolah berasrama sebagai representasi perpaduan sistem sekolah dan sistem pesantren.

\section{METODE PENELITIAN}

Penelitian ini merupakan jenis penelitian kualitatif-naturalistik, yaitu penelitian yang ditujukan untuk mendeskripsikan suatu fenomenafenomena secara apa adanya (Sudaryono, 2014). Unit analisis penelitian ini bertempat di SMAIT Ihsanul Fikri Boarding School yang berada di Mungkid, Magelang dan SMAI Al Azhar Boarding School di Yogyakarta sebagai representasi sekolah berasrama. Cakupan penelitian terutama difokuskan pada bagaimana aspek kelembagaan melibatkan unsur sekolah dan asrama dalam kerangka pengelolaan secara integral, konsekuensi implementasi kurikulum pendidikannya dan hubungan kesaling-terkaitan antara keduanya.
Jenis data yang digali adalah data kualitatif yang berada pada key informant yakni ketua yayasan dan mudir (direktur) dan informant yakni pengurus yayasan, kepala sekolah, wakil kepala sekolah bidang kurikulum dan manajer atau pengelola asrama (boarding). Instrumen penelitian ini menggunakan peneliti sebagai alat penelitian. Dalam fungsi ini, peneliti dibekali pedoman wawancara dan panduan pengamatan serta daftar dukumen. Dengan demikian metode pengumpulan data yang digunakan dalam penelitian ini meliputi wawancara, observasi dan dokumentasi.

Data digali, dianalisis dan disimpulkan mengacu pada data bukan pada peneliti. Pertanyaan diajukan kepada key informan/informan dengan menggunaka model stimulus dan respons, terbuka atau tertutup, argumentatif atau eksploratif. Peneliti mentranskrip jawaban dari key informan/informan untuk dianalisis lebih lanjut. Sumber data juga diperoleh dari dokumentasi yang ada di sekolah dan publikasi sekolah yang dimintakan ijin kepada pihak otoritas sumber data. Disamping itu juga dilakukan pengamatan langsung yang diketahui oleh sumber otoritas data.

Untuk memastikan kevalidan data, digunakan triangulasi sumber dan triangulasi teknik. Adapun teknik analisis data dalam penelitian ini menggunakan metode analisis-deskriptif dengan pendekatan induktif. Langkah-langkah dalam analisis data ini, sebagaimana dikembangkan oleh Miles dan Huberman, meliputi reduksi data, penyajian data dan penarikan kesimpulan. (Miles \& Huberman, 1992).

\section{HASIL DAN PEMBAHASAN}

\section{Pola Pengelolaan Sekolah Islam Berasrama}

Pengelolaan kelembagaan sekolah berasrama yang berlaku di SMAIT Ihsanul Fikri Boarding School dan SMAI Al Azhar Boarding School menunjukkan sesuatu 
yang berbeda. Meski sama-sama menambahkan unsur asrama sebagai representasi pesantren dalam penyelenggaraan pendidikannya, kedua lembaga ini menerapkan pola pengelolaan yang berbeda terkait bagaimana unsur sekolah dan unsur asrama dikelola dalam satu kerangka kelembagaan yang utuh. Kelembagaan dalam hal ini dipahami sebagai sebuah aturan main yang berlaku dalam sebuah kelompok yang disepakati oleh anggotanya sebagai sesuatu yang harus diikuti dan dipatuhi dengan tujuan terciptanya keteraturan dan kepastian interaksi sesama anggota (Syarif, 2013). Berdasarkan pemahaman tersebut, pengelolaan kelembagaan pada sekolah berasrama yang merupakan kombinasi sistem pesantren dan sistem persekolahan selayaknya dijalankan dalam satu kerangka pengelolaan yang utuh dan saling terkait.

Pola pengelolaan sekolah berasrama tersebut dapat dilihat terutama dari struktur organisasi kelembagaan yang ada di masing-masing lembaga. Hal ini mengingat bahwa istilah kelembagaan dan organisasi bersifat interchangeably (Syarif, 2013). Dari struktur organisasi yang ada pada suatu lembaga pendidikan akan terlihat bagaimana posisi atau kedudukan serta hubungan kesaling-terkaitan antara tiap unsur kelembagaan yang ada. Dalam konteks sekolah berasrama, struktur organisasi pengelolaan tersebut menjelaskan bagaimana keterpaduan unsur asrama dan unsur sekolah yang diselenggarakan dalam satu sistem terpadu.

Dengan mengacu pada struktur organisasi yang ada di SMAIT Ihsanul Fikri Boarding School, dapat diketahui bahwa pengelolaan asrama berada di bawah tanggung jawab Wakil Kepala Sekolah Bidang Keasramaan yang bertanggung jawab kepada Kepala sekolah. Tidak seperti yang berlaku di lembaga lain, dimana umumnya penanggung jawab asrama memiliki posisi yang sejajar dengan kepala sekolah, pengelola asrama di SMAIT Ihsanul Fikri Boarding School berposisi sejajar dengan wakil kepala sekolah lainnya seperti bidang kurikulum, kesiswaan dan lainnya (Muallimin, 2020). Hal ini menunjukkan bahwa kepala sekolah bertanggung jawab dan terlibat secara langsung dan menyeluruh pada proses pendidikan baik di sekolah maupun di asrama.

Pengelolaan asrama di bawah wakil kepala sekolah yang bertanggung jawab kepada kepala sekolah, bukan oleh pihak yang bertanggung jawab langsung kepada direktur atau ketua yayasan, secara tidak langsung dapat dipahami sebagai upaya sekolah men-setting berjalannya aktifitas di asrama sesuai dan selaras dengan yang dibutuhkan oleh sekolah. Dengan begitu, sentimen kelembagaan antara sekolah dengan asrama dapat dihilangkan karena asrama berada dalam kendali kepala sekolah. Dengan struktur pengelola yang demikian itu, pengelolaan dilakukan dengan pendekatan yang lebih menyatu, pengelolaan asrama juga dirasa akan lebih terkontrol dan tersambung secara lebih dekat dengan visi dan misi sekolah. Pengelolaan yang demikian di satu sisi menunjukkan pengelolaan yang lebih terpadu, meski secara organisatoris asrama/pondok tereduksi bukan sebagai lembaga yang "sepadan" dengan sekolah sebagai representasi pesantren, malainkan sebagai sub-sistem yang menyokong berjalannya sistem persekolahan.

Dalam konteks SMAIT Ihsanul Fikri Boarding School, istilah asrama dan pondok pesantren berlaku secara bergantian, terutama ketika berbicara mengenai kegiatan asrama. Meski pengelolaan asrama tidak berada dibawah kendali pondok pesantren, wakil kepala sekolah bidang keasramaan juga berkoordinasi dengan pimpinan pondok sebagai bentuk pertanggung jawaban, karena bagaimanapun asrama yang dijalankan juga merepresentasikan atau menjalankan program dan kegiatan yang menggambarkan aktifitas pesantren. Dalam kesehariannya, peserta didik di asrama 
mendapatkan pembelajaran yang dikelola oleh pondok, sehingga Waka Keasramaan juga harus berkoordinasi terutama terkait waktu dan pengkondisian peserta didik.

Kemudian dalam hal pengelolaan kegiatan yang dijalani oleh peserta didik dalam kesehariannya, di SMAIT Ihsanul Fikri Boarding School, kegiatan peserta didik meliputi kegiatan di sekolah dan kegiatan di asrama. Kegiatan di sekolah merupakan kegiatan yang secara umum berlaku pada sistem persekolahan pada umumnya, terutama sekolah Islam terpadu. Kegiatan sekolah biasanya dimulai pada pukul 06.20 WIB yang diawali dengan program Alqur'an time sebelum KBM berlangsung dan secara formal berakhir pada pukul 14.50 WIB, kecuali bagi peserta didik yang mengikuti jadwal ektrakurikuler ataupun les tambahan yang selesai pada pukul 17.10 WIB. Seluruh kegiatan persekolahan ini dijalankan hampir sama persis dengan yang berlaku di sekolah pada umumnya, sedikit perbedaan yang ada barangkali hanya bahwa dengan sistem asrama yang diterapkan, IFBS diuntungkan dengan mobilisasi peserta didik yang lebih mudah.

Sementara itu, kegiatan asrama sepenuhnya merupakan kegiatan yang berjalan di luar jam kegiatan sekolah. Kegiatan asrama dimulai setelah kegiatan sekolah yang secara umum selesai pada pukul 17.10 WIB dan secara garis besar selesai setelah peserta didik masuk pada jam kegiatan sekolah pada keesokan harinya. Hampir semua kegiatan yang berlangsung di asrama merupakan kegiatan mandiri, kecuali kegiatan kajian yang masuk dalam agenda pondok. Meski begitu, semua kegiatan yang berlangsung di jam asrama ini didampingi dan dipantau oleh musyrif atau pembina yang memang bertanggungjawab pada kehidupan sosial sehari-hari antar peserta didik di asrama.

Berbeda dengan SMAIT Ihsanul Fikri Boarding School, pengelolaan kelembagaan antara sekolah dan asrama di SMAI Al Azhar Boarding School dilakukan secara lebih mandiri. Dengan mengacu pada bagan struktur organisasinya, pengelolaan unsur kelembagaan antara sekolah dan asrama berada di bawah tanggung jawab orang yang berbeda. Pengelolaan sekolah, sebagaimana umumnya, berada di bawah tanggung jawab seorang kepala sekolah, sementara pengelolaan asrama/boarding berada dibawah seorang manajer yang secara struktur berada di bawah kepala sekolah. Namun demikian, berdasarkan informasi yang diperoleh, pengelolaan asrama/boarding berjalan dengan semiindependent, hubungan dengan sekolah berupa koordinasi dan bukan instruksi, karena manajer asrama tidak bertanggung jawab kepada kepala sekolah (Jainudin, 2020).

Dengan pola yang demikian, penyelenggaraan pendidikan di asrama/boarding lebih difokuskan pada bagaimana agar dapat selaras dengan unit sekolah. Penyelenggaraan pendidikan di asrama/boarding bahkan harus mendukung keberlangsungan dan kesuksesan penerapan kurikulum yang ada di unit sekolah (Rosyid, 2020). Pada titik tertentu, penyelenggaraan pendidikan yang demikian itu berkaitan dengan kenyataan bahwa bentuk pengelolaan yang diterapkan adalah tidak all boarding, yang semua peserta didiknya tidak tinggal di asrama, sehingga dengan program-program asrama yang menyokong penyelenggaraan kurikulum di unit sekolah, peserta didik yang tinggal di asrama dapat memperlihatkan kelebihan dibandingkan mereka yang tidak di asrama, baik dari sisi penguasaan pelajaran sekolah dan lebihlebih dari sisi karakter dan sikap yang ditampilkan setiap harinya. Meski begitu, asrama/boarding tetap memiliki program khusus asrama sebagai bentuk pengayaan serta untuk tetap menunjukkan karakter boarding school seperti program Pendalaman Materi Keagamaan dan Akademik (PMKA), program santri 
unggulan, program takhasus tahfidz Qur'an, serta Science dan teknologi.

Dalam hal hubungan kesaling-terkaitan dengan sekolah, pada titik tertentu boarding/asrama dapat dikatakan sebagai komponen yang berfungsi sebagai supporting system dari sekolah. Kegiatankegiatan yang dijalankan di luar jam kegiatan KBM di unit sekolah sepenuhnya menjadi tanggung jawab pengelola asrama di bawah tanggung jawab manajer. Pengelolanya pun sepenuhnya terpisah, tanpa ada percampuran personalia antara sekolah dan asrama. Namun demikian, secara konten dan substansinya, hampir semua kegiatan tersebut berjalan selaras dan mendukung pelaksanaan pendidikan yang ada di unit sekolah. Untuk memperlancar pelaksanaan kegiatan di asrama tersebut, pengelolaan peserta didik dibagi berdasarkan kelas di unit sekolah. Setiap kelasnya diatur untuk menempati satu lantai gedung asrama. Pembagian peserta didik dengan model yang demikian itu dilakukan dengan pertimbangan bahwa pembelajaran atau ta'lim yang dilaksanakan di boarding/asrama juga disesuaikan dengan level kelasnya. Setiap kelas mendapatkan materi yang berbeda meskipun subjek pelajarannya sama, seperti fikih. Dengan model pembagian yang demikian tersebut, pembelajaran diatur agar tidak terjadi benturan atau tumpang tindih materi serta agar peserta didik mendapatkan pembelajaran yang sesuai dengan kemampuannya. Ini sekaligus agar ketika tahun ajaran baru datang, peserta didik yang telah tinggal di asrama tidak mengulang materi pembelajaran, namun berpindah atau naik tingkat pada level materi pembelajaran yang berikutnya.

\section{Implementasi Kurikulum Sekolah Berasrama}

Sebagai konsekuensi dari pola pengelolaan yang berlaku di sekolah berasrama, terutama dalam kasus SMAIT Ihsanul Fikri Boarding School dan SMAI Al Azhar Boarding School, penyelenggaraan kurikulum pendidikan di dalamnya juga ikut terpengaruhi dengan adanya sistem kombinasi tersebut.

Dalam kasus SMAIT Ihsanul Fikri Boarding School, kurikulum pendidikan yang diterapkan adalah kurikulum sekolah menengah atas terpadu dengan mengikuti pola yang dikembangkan dalam JSIT. Perbedaannya adalah bahwa disini menerapkan sistem asrama yang berimplikasi pada ketersediaan waktu yang lebih lama. Implementasi kurikulum disesuaikan dengan mengkombinasikan isi kurikulum dinas dan standar JSIT. Kombinasi ini dilakukan tanpa mengurangi jumlah atau nomenklatur mata pelajaran yang sudah menjadi ketentuan dinas, hanya saja dilakukan penyesuaian-penyesuaian seperti mengurangi jam mata pelajarannya. Sedangkan penambahan kurikulum keagamaan berdasarkan standar JSIT dilakukan dengan menjabarkan secara terperinci mata pelajaran Pendidikan Agama dan Budi Pekerti ke dalam beberapa subjek mata pelajaran, yaitu Aqidah-akhlak, Fikih, Alqur'an-Hadis, dan SKI. Selain itu ditambah pula mata pelajaran tahfidz sebagai ciri khusus yang ada di SMAIT Ihsanul Fikri.

Adapun dalam kasus SMAI Al Azhar Boarding School, dengan melihat kenyataan bahwa pengelolaan sekolah dan Asrama/Boarding dilakukan secara terpisah, implementasi kurikulum pada keduanya pun juga nampak terpisah. Barangkali hanya pada titik-titik tertentu terdapat hubungan atau koordinasi antara keduanya, selebihnya semua dijalankan secara mandiri. Namun begitu, pola hubungan yang demikian tersebut terus dievaluasi dan seiring berjalannya waktu diharapkan akan dapat menemukan formulasi yang tepat bagi penyelenggaraan pendidikan di SMA-Boarding School Al Azhar Yogyakarta.

Kurikulum pada unit sekolah mengacu pada kurikulum dinas dan kurikulum YPI Al Azhar yang dipadukan menjadi satu. Secara umum, struktur isi kurikulum di SMA Islam Al Azhar Yogyakarta tidak 
jauh berbeda dengan kurikulum dinas, hanya terdapat sedikit penambahan sesuai standar YPI berupa pengembangan mata pelajaran PAI, Al-Qur'an, dan Bahasa Arab. Selain dalam bentuk mata pelajaran, kurikulum sebagai sebuah sarana memberikan pengalaman di Al Azhar juga dalam bentuk pelaksanaan kegiatan keagamaan sebagai pembiasaan seperti tadarrus, shalat dhuha, shalat dzuhur berjamaah serta beberapa pengaplikasian beberapa aspek dengan muatan keislaman sebagaimana pada sekolah Islam terpadu lainnya.

Sementara itu, dalam konteks asrama/boarding sebagai bagian integral dalam sistem pendidikan berasrama, kurikulum pendidikan antara SMAIT Ihsanul Fikri Boarding School dan SMAI Al Azhar Boarding School juga berbeda. Pada sistem asrama di SMAIT Ihsanul Fikri, kurikulum pendidikan yang diberikan terbatas pada habituasi dengan menekankan ketaatan beribadah baik yang wajib maupun yang sunnah, bersosialisasi dengan sesama dengan santun serta penanaman karakter islami lainnya. Dari aspek pengetahuan keislaman, pengelola asrama menjadwalkan kajian kontemporer sebanyak tiga kali dalam satu minggu yang disampaikan atas nama pondok yang bekerjasama dengan pihak asrama (Sukari, 2020)

Adapun pada sistem asrama di SMAI Al Azhar Boarding School, kurikulum pendidikan yang diberikan meliputi habituasi dan juga pembelajaran. Sebagaimana di asrama pada umumnya, habituasi dilakukan sebagai sarana mengamalkan ajaran agama serta membentuk karakter yang islami. Sementara itu, pembelajaran di asrama meliputi tahsin-tahfid, pengayaan bahasa serta ta'lim yang di dalamnya berupa kajian-kajian kitab kuning layaknya di pesantren salaf. Berbeda dengan sistem asrama di SMAIT Ihsanul Fikri, sistem asrama di SMAI Al Azhar ini menerapkan evaluasi pembelajaran berupa ujian akhir untuk melihat pencapaian peserta didik dalam penguasaan materi pembelajaran ( $\mathrm{ta}$ 'lim) yang telah disampaikan (Jainudin, 2020).

\section{Pengelolaan Sekolah Islam Berasrama dan Gambaran Lulusan yang Ideal}

Unsur asrama yang berada dalam sistem sekolah berasrama seringkali diasosiasikan sebagai bentuk lain dari sistem pesantren. Keberadaannya yang melengkapi sistem sekolah dalam kerangka perpaduan sistem pendidikan diharapkan dapat menjadikan pendidikan yang diselenggarakan menjadi lebih komprehensif. Keberadaan asrama juga sekaligus merupakan pembeda dengan sekolah reguler yang umumnya hanya beroperasi 6-8 jam. Meski begitu, sebagai lembaga pendidikan yang diklaim merupakan kombinasi dari sistem pesantren dan sistem sekolah, pengelolaan kelembagaan sekolah berasrama belum memiliki pola yang baku serta masih memerlukan konsep keterpaduan yang dapat menunjukkan keselarasan dan kesinambungan (Muhdi, 2018). Konseptualisasi pengelolaan ini penting agar sebagai lembaga yang dibangun dari fondasi dua kelembagaan, sekolah berasrama tidak menunjukkan sesuatu yang dualis, namun benar-benar terpadu. Begitu pula dari sisi tujuan, perpaduan sekolahpesantren yang direpresentasikan sekolah Islam berasrama ini juga harus terpadu, bukan parsial dan cenderung menyempit sebagaimana ketika berdiri sendiri-sendiri (Amrizal, 2011).

Pengelolaan kelembagaan yang mencerminkan keterpaduan lembaga serta kesatuan sistem yang segala sesuatunya saling terkait dan saling mempengaruhi berpeluang lebih besar dalam usaha menciptakan lulusan yang unggul, yaitu lulusan yang menguasai pengetahuan umum dan pengetahuan agama dengan baik serta memiliki karakter yang mulia. Pola pengelolaan yang demikian juga akan meminimalisir kemungkinan salah satu sistem tereduksi dalam sistem yang lain. 
Dengan begitu, keunggulan-keunggulan yang ada dalam sistem pesantren maupun sistem persekolahan dapat diakomodir dengan seimbang.

Hal tersebut terkait pula dengan bagaimana kurikulum diterapkan dalam kerangka kombinasi dan integrasi. Kurikulum secara umum dapat dipahami sebagai sesuatu yang berkenaan dengan apa yang akan diberikan kepada peserta didik sebagai sarana mencapai tujuan, baik yang berupa pengetahuan ilmiah yang dibingkai dalam bentuk mata pelajaran atau yang berupa pengalaman belajar yang dikemas dalam berbagai bentuk program atau kegiatan (Idi, 2007; Munir, 2008). Hal ini menunjukkan bahwa segala sesuatu yang memberikan kontribusi pada pencapaian tujuan pendidikan suatu lembaga pendidikan dapat disebut sebagai bagian kurikulum, bukan hanya berupa mata pelajaran yang diajarkan kepada peserta didik.

Dalam konteks sekolah berasrama, kombinasi sistem persekolahan dan sistem pesantren menyiratkan keharusan untuk mengkombinasikan pula kurikulum dari masing-masing sistem tersebut. Umumnya, dalam pengertian yang sempit, kurikulum sekolah terdiri dari serangkaian mata pelajaran yang telah ditetapkan oleh pemerintah dalam bentuk kurikulum nasional. Secara garis besar kurikulum nasional tersebut dikenal dengan istilah pengetahuan umum karena didominasi oleh subjek-subjek non-keagamaan. Sementara itu kurikulum pesantren umumnya hanya berupa subjek-subjek keagamaan yang dimaksudkan agar peserta didik menguasai pengetahuan agama secara luas. Namun dalam sistem pesantren diakui pula terdapat komponen yang tidak dimiliki sistem persekolahan yaitu bagaimana sistem pesantren pembentuk akhlak serta sikap hidup peserta didiknya (Zainudin, 2017). Kurikulum pesantren tersebut secara garis besar tergambarkan dalam fungsinya, yang oleh Azra (2000) diklasifikasikan ke dalam tiga fungsi yaitu sebagai transmisi pengetahuan Islam, pemeliharaan tradisi dan reproduksi ulama. Dalam bentuk lain tergambar dalam orientasi yang moderat sebagai piranti membentuk moderasi pendidikan (Khojir, 2020)

Implementasi kurikulum pada sekolah berasrama sebagai manifestasi dari kombinasi sistem persekolahan dan sistem pesantren dalam praktiknya cukup bervariasi. Pola-pola yang diterapkan dalam mengkombinasikan atau mengintegrasikan kurikulum tersebut antara satu lembaga dengan lembaga yang lain cukup beragam, di antaranya dengan memasukkan kurikulum pesantren dalam pembelajaran sekolah (Zulfatun \& Arifin, 2017) atau menerapkan kurikulum pada masing-masing unsur kelembagaan yang terintegrasi (Agus, 2013). Pada kasus SMAIT Ihsanul Fikri Boarding School dan SMAI Al Azhar Boarding School, implementasi kurikulum kombinasi yang diterapkan antara keduanya ternyata juga menunjukkan perbedaan.

Pada umumnya, kombinasi atau integrasi yang berlangsung pada sekolah Islam terpadu berkutat pada pengintegrasian kurikulum dinas dengan nilai dan prinsip Islam serta tambahan beberapa mata pelajaran keislaman (Azra, 2015; Hasan, 2009; Hefner, 2009; Tan, 2014). Demikian pula yang terjadi dalam diskursus integrasi di kedua lembaga pendidikan Islam di atas. Dalam kontek pembelajaran di sekolah, kedua lembaga pendidikan Islam ini berusaha mengkombinasikan kurikulum dinas dengan tambahan mata pelajaran keagamaan serta nilai dan prinsip Islam.

Namun demikian, kedua lembaga ini berbeda dalam hal bagaimana memposisikan dan menyelenggarakan kurikulum pada ranah asrama/boarding. Perbedaan dalam hal penyelenggaraan kurikulum dalam sistem asrama ini disinyalir karena pengaruh dari pola pengelolaan kelembagaan serta sumber daya yang dimiliki oleh masing-masing. Jika mengacu pada klasifikasi yang 
diajukan Muhdi (2018), implementasi kurikulum yang dijalankan di SMAIT Ihsanul Fikri Boarding School lebih condong kepada integrasi sistemik. Sedangkan implementasi kurikulum yang berlaku di SMAI Al Azhar Boarding School lebih dekat kepada model integrasi organik.

Dari sisi kelembagaan, pola pengelolaan yang digambarkan oleh dua lembaga pendidikan berasrama di atas akan mengarahkan pada sebuah kesimpulan berkaitan dengan terma keterpaduan lembaga. Pola pengelolaan yang diterapkan tersebut menunjukkan sejauh mana sistem yang dijalankan dapat merepresentasikan dua lembaga yang dikombinasikan, apakah cenderung tampak sebagai satu kesatuan lembaga yang menyatu atau tetap menunjukkan diferensiasi antara sekolah dan pesantren.

Begitu pula dengan implementasi kurikulum yang akan menunjukkan unsur manakah yang tereduksi. Hal ini dapat dilihat pada prosentase pengakomodasian kurikulum, baik kurikulum sekolah maupun kurikulum pesantren, yang diselenggarakan pada sistem sekolah berasrama tersebut. Penyelenggaraan kurikulum yang demikian ini akan berimplikasi pada sejauh mana idealitas lulusan dari gabungan sistem sekolah dan sistem pesantren dapat dicapai. Pengakomodasian kurikulum yang tidak seimbang dan proporsional dari dua sistem pendidikan yang ada berpotensi mengurangi atau bahkan menghilangkan keunggulan dari salah satunya.

Dengan melihat penerapan kurikulum sekolah berasrama baik di SMAIT Ihsanul Fikri Boarding School maupun di SMAI Al Azhar Boarding School, penekanan pada sistem persekolahan dengan berbagai dimensi dan fungsinya tampak lebih ditonjolkan. Sementara sistem pesantren yang termanifestasikan dalam bentuk asrama belum sepenuhnya terakomodasi secara komprehensif. Fungsi pesantren, sebagaimana diklasifikasikan Azra (2000), sebagai tempat reproduksi ulama nampaknya belum cukup terakomodasi dalam sistem sekolah berasrama. Hal tersebut tercermin dari jenis dan level keilmuan yang diajarkan di sekolah berasrama yang berbeda dengan pesantren. Namun demikian, fungsi transmisi pengetahuan dan pemelihara tradisi nampak terakomodasi dengan baik melalui berbagai kegiatan dan program yang dijalankan dalam penyelenggaraan sekolah berasrama.

\section{KESIMPULAN DAN REKOMENDASI}

Berdasarkan temuan dan pembahasan yang telah dipaparkan di atas, dapat disimpulkan bahwa: Pertama, pengelolaan kelembagaan sekolah berasrama yang merupakan manifestasi dari kombinasi sistem persekolahan dan sistem pesantren memiliki perbedaan pola. Hal tersebut terutama berkenaan dengan posisi stuktural penanggung jawab asrama yang secara tidak langsung menggambarkan seperti apa posisi dan hubungan keterkaitan antara dua unsur kelembagaan dalam satu bangunan sistem tersebut. Kedua, implementasi kurikulum sebagai konsekuensi dari perpaduan dua unsur kelembagaan yang terwujud dalam satu bangunan sistem sekolah berasrama juga menunjukkan perbedaan. Perpaduan kurikulum sekolah dan pesantren dalam kurikulum sekolah berasrama menunjukkan pola yang berbeda, antara mereduksi dengan beberapa penyesuaian serta mempertahankan karakter kurikulum masing-masing dalam setiap unsur kelembagaannya. Penyelenggaraan kurikulum sekolah berasrama yang demikian itu akan menentukan sejauh mana gambaran ideal lulusan sekolah berasrama dapat diwujudkan.

Merujuk pada kesimpulan tersebut di atas, secara umum tampak bahwa sistem sekolah cenderung lebih diunggulkan, dimana adopsi sistem pesantren dalam wujud asrama tidak dapat dilakukan secara menyeluruh. Peran, fungsi serta dimensi yang melekat pada pesantren sebagai karakter kelembagaan sepenuhnya dapat 
diakomodasi. Hal ini tentunya akan berimplikasi pada kualitas output sekolah dengan sistem asrama yang melenceng dari apa yang diidealkan dari perpaduan sistem tersebut. Karenanya, pengelolaan kelembagaan serta penerapan kurikulum dalam sistem sekolah berasrama perlu diarahkan pada pengelolaan yang lebih sinergis, yang mengakomodasi dimensidimensi dari kedua sistem secara proporsional tanpa mereduksi salah satunya. Dengan begitu, gambaran ideal output dari perpaduan sistem sekolah dan sistem pesantren dapat wujudkan secara lebih maksimal.

\section{REFERENSI}

Agus, D. M. Q. (2013). Manajemen Pondok Pesantren Dalam Mengintegrasikan Kurikulum Pesantren Dengan Pendidikan Formal. EduIslamika2, 5(02).

Amrizal. (2011). Sekolah Versus Pesantren; Sebuah Perbandingan Menuju Format Baru Mainstream Lembaga Pendidikan Nasional Peniada Dikotomik. Jurnal Sosial Budaya, 8(01), 114-131.

Arifin, Z. (2012). Pengembangan Manajemen Mutu Kurikulum Pendidikan Islam. Yogyakarta: Diva Press.

Azra, A. (2000). Pendidikan Islam Tradisional dan Modernisasi Menuju Milinium Baru (II). Jakarta: Logos.

Azra, A. (2015). Genealogy of Indonesian Islamic Education: Roles in The Modernization of Muslim Society. Heritage of Nusantara; International Journal of Religious Literature and Heritage, 4(1).

Fauzan, F. (2017). Urgensi Kurikulum Integrasi di Pondok Pesantren dalam Membentuk Manusia Berkualitas. Fikrotuna, 6(2), 600-617. https://doi.org/10.32806/jf.v6i2.3097

Hasan, N. (2009). Islamizing Formal Education: Integrated Islamic School and a New Trend in Formal Education
Institution in Indonesia (No. 172). Singapore.

Hefner, R. W. (2009). Islamic School, Social Movement, and Democracy in Indonesia. In R. W. Hefener (Ed.), Making Modern Muslims; The Politics of Education in Southeast Asia. Hawai: University of Hawai'i Press.

Idi, A. (2007). Pengembangan Kurikulum; Teori dan Praktik. Yogyakarta: ArRuzz Media.

Khojir, K. (2020). Moderasi Pendidikan Pesantren Di Kalimantan Timur. Ta'dib, 23(1), 95-106. https://doi.org/10.31958/jt.v23i1.1945

Kosim, M. (2006). Pendidikan Agama Islam di Sekolah Umum (Perspektif Sosio-Politik-Historis). Tadris, 1(2), 119-137.

Lukens-Bull, R. (2005). A Peaceful Jihad; Negotiating Identity and Modernity in Muslim Java. England: PALGRAVE MACMILLAN.

Magdalena. (2013). Pendidikan Agama Islam di Sekolah Umum. Ta'allum, 01(2), 119-132.

Maghfuri, A., \& Rasmuin. (2019). Dinamika Kurikulum Madrasah Berbasis Pesantren Pada Abad Ke 20 (Analisis Historis Implementasi Kurikulum Madrasah). Tadbir; Jurnal Studi Manajemen Pendidikan, 3(1), 116.

Maksudin. (2012). Sistem Boarding School SMP Islam Terpadu Abu Bakar Yogyakarta (Transformasi dan Humanisme Religius). Cakrawala Pendidikan2, 31(1), 38-54. https://doi.org/10.1177/0308575907031 00114

Maksum. (1999). Madrasah: Sejarah dan Perkembangannya. Jakarta: Logos Wacana Ilmu.

Miles, M. B., \& Huberman, A. M. (1992). Analisis Data Kualitatif: Buku Sumber Tentang Metode-Metode Baru. Jakarta: UI Press.

Muhdi, A. A. (2018). Management Of Integrated Education Between 
Pesantren And Campus In Improving The Quality Of Graduates ( Multisites Study In Ma'Had Dalwa Bangil And Pondok Ngalah Purwosari Pasuruan East-Java ). Didaktika Religia, 6(1), 167-190.

Munir. (2008). Kurikulum Berbasis Teknologi Informasi dan Komunikasi. Bandung: Alfabeta.

Saepudin, J. (2019). Pendidikan Agama Islam Pada Sekolah Berbasis Pesantren: Studi Kasus Pada SMP Al Muttaqin Kota Tasikmalaya. EDUKASI: Jurnal Penelitian Pendidikan Agama Dan Keagamaan, 17(2), 172-187.

Sudaryono. (2014). Educational Reasearch Methodology. Jakarta: Lentera Ilmu Cendekia.

Suyatno. (2013). Sekolah Islam Terpadu; Filsafat, Ideologi, dan Tren Baru Pendidikan Islam di Indonesia. Jurnal Pendidikan Islam, II(2), 355-378.

Syarif, M. (2013). Teori dan Model Pengembangan Kelembagaan
Pendidikan Tinggi Islam. Media Akademika, 28(3), 333-362.

Tan, C. (2014). Educative Tradition and Islamic Schools in Indonesia. Journal of Arabic and Islamic Studies, 14, 4762.

Thohir, K. (2017). Kurikulum Dan Sistem Pembelajaran Pondok Pesantren Salafi Di Kecamatan Kresek Kabupaten Tangerang Provinsi Banten. Jurnal Analytica Islamica, 6(1), 11-21.

Yasmadi. (2002). Modernisasi Pesantren: Kritik Nurcholish Madjid Terhadap Pendidikan Islam Tradisional. Jakarta: Ciputat Press.

Zainudin. (2017). Tradisi Keilmuan Dalam Dunia Pesantren dan Pendidikan Formal. Schemata, 6, 81-92.

Zulfatun, S., \& Arifin, Z. (2017). Implementasi Pengembangan Kurikulum di SMP Muhammadiyah Boarding School (MBS) Yogyakarta. Tadris, 12(1), 85. 